\title{
Hysteresis and thermodynamic properties of water sorption in 'Malagueta' pepper seeds
}

\author{
Hellismar W. da Silva ${ }^{1}$, Renato S. Rodovalho ${ }^{2}$ \& Isneider L. Silva ${ }^{3}$ \\ ${ }^{1}$ Universidade Federal de Lavras/Departamento de Agricultura. Lavras, MG. E-mail: waksonhellismar@gmail.com (Corresponding author) - \\ ORCID: 0000-0002-1353-2247 \\ ${ }^{2}$ Instituto Federal de Educação Ciência e Tecnologia Goiano/Campus Ceres/Curso de Bacharelado em Agronomia. Ceres, GO. E-mail: \\ souzarodovalho@gmail.com - ORCID: 0000-0002-0558-4098 \\ ${ }^{3}$ Universidade Estadual de Goiás. Anápolis, GO. E-mail: isneider.luiz@gmail.com - ORCID: 0000-0002-0609-3274
}

\section{Key words:}

Capsicum frutescens $\mathrm{L}$.

enthalpy

entropy

Gibbs free energy

\begin{abstract}
A B S T R A C T
The objective of this study was to determine hysteresis, enthalpy, entropy, enthalpy-entropy compensation theory and Gibbs free energy for water adsorption and desorption in 'Malagueta' pepper seeds. Hygroscopic equilibrium moisture contents were determined by the static gravimetric method, with water activity in the range from 0.29 to 0.90 and temperatures of 30,40 and $50^{\circ} \mathrm{C}$. The hysteresis of the 'Malagueta' pepper seeds reduces with the increase of temperature. Enthalpy, entropy and Gibbs free energy of adsorption and desorption increase with the reduction of the moisture content of the seeds. The enthalpy-entropy compensation theory is valid for the sorption processes. The sorption of water between seeds and the surrounding air is a non-spontaneous process.
\end{abstract}

\section{Histerese e propriedades termodinâmicas de sorção de água em sementes de pimenta malagueta}

\section{R E S U M O}

Objetivou-se, neste trabalho, determinar histerese, entalpia, entropia, teoria da compensação entalpia-entropia e a energia livre de Gibbs para os processos de adsorção e dessorção de água em sementes de pimenta malagueta. Os teores de água de equilíbrio higroscópico foram determinados pelo método estático gravimétrico, com atividade de água na faixa de 0,29 a 0,90 e temperaturas de 30,40 e $50^{\circ} \mathrm{C}$. A histerese das sementes de pimenta malagueta reduz com o aumento da temperatura. A entalpia, entropia e energia livre de Gibbs de adsorção e dessorção aumentam com a redução do teor de água das sementes. A teoria da compensação entalpia-entropia é válida para os processos sortivos. A sorção da água entre as sementes e o ar envolvente é um processo não espontâneo. 


\section{INTRODUCTION}

Peppers and bell peppers of the genus Capsicum are traditionally used in Brazilian cuisine. Red pepper products, usually from the 'Malagueta' variety, pungent or non-pungent, characterize the peppers as one of the world's most important spice commodities (Heinrich et al., 2015). It is estimated that in 2016 the world production of fresh peppers and bell peppers has reached 51.9 million tons (FAOSTAT, 2018), which can be justified by the use of production technologies such as highquality seeds.

Due to the hygroscopic behavior, the moisture content of seeds is influenced by the temperature and relative humidity of the air (Silva \& Rodovalho, 2016). This behavior directly interferes with the biological activity and longevity of these seeds (Silva et al., 2015b).

The hygroscopicity of a product is defined as its ability to release or absorb water from the environment, phenomena known as water desorption and adsorption (Corrêa et al., 2014). The difference between adsorption and desorption isotherms (hysteresis) allows the evaluation of chemical and microbiological deterioration and stability of the product during storage (Goneli et al., 2016b).

From the isotherms, it is possible to determine thermodynamic parameters related to water sorption, such as enthalpy, entropy, enthalpy-entropy compensation theory and Gibbs free energy (Nkolo Mezee et al., 2008; Oliveira et al., 2013; Silva et al., 2016). These thermodynamic parameters are essential to analyze the binding forces between water molecules and the product during the sorption processes (Costa et al., 2015; Yogendrarajah et al., 2015) and determine the minimum energy required in drying processes (Costa et al., 2013).

This study aimed to determine hysteresis, enthalpy, entropy, enthalpy-entropy compensation theory and Gibbs free energy related to water adsorption and desorption in 'Malagueta' pepper seeds.

\section{Material ANd Methods}

The experiment was conducted at the Food Laboratory of the Federal Institute of Goiás - Campus of Ceres, GO, Brazil ( $15^{\circ} 16^{\prime} 30^{\prime \prime}$ S; $49^{\circ} 35^{\prime} 54^{\prime \prime}$ W). Pepper seeds of the 'Malagueta' variety (Capsicum frutescens $\mathrm{L}$.) were manually extracted from ripe fruits (completely red), harvested between January and March 2011 in the experimental area of the same institution.

After extraction, the seeds were subjected to pre-drying for $48 \mathrm{~h}$ under laboratory conditions to remove excess moisture content and divided into two samples. The first sample, with moisture content of approximately $46.0 \%$ (d.b.), was used in the desorption process; and the second one, used for the study on the adsorption process, was subjected to oven drying at temperature of $70^{\circ} \mathrm{C}$ for $48 \mathrm{~h}$, until it reached moisture content close to $2.5 \%$ (d.b.). The moisture content of the seeds was determined by the gravimetric method in an oven at $105 \pm 3{ }^{\circ} \mathrm{C}$ for $24 \mathrm{~h}$ (Brasil, 2009).

Hysteresis was obtained by the difference between desorption and adsorption equilibrium moisture contents, calculated using the Modified Oswin model (Eqs. 1 and 2, respectively). These models were recommended to represent the desorption isotherms (Silva \& Rodovalho, 2012) and adsorption isotherms (Silva \& Rodovalho, 2016) of 'Malagueta' pepper seeds at temperatures of 30,40 and $50{ }^{\circ} \mathrm{C}$ and water activity ranging from 0.29 to 0.90 (dimensionless).

$$
\begin{aligned}
& \mathrm{Xe}=\frac{\left[17.8500^{* *}+\left(-0.1795^{* *}\right) \mathrm{T}\right]}{\left[\frac{\mathrm{a}_{\mathrm{w}}}{\left(1-\mathrm{a}_{\mathrm{w}}\right)}\right]^{\frac{1}{3.2995^{* *}}}} \\
& \mathrm{Xe}=\frac{\left[12.2714^{* *}+\left(-0.0912^{* *}\right) \mathrm{T}\right]}{\left[\frac{\mathrm{a}_{\mathrm{w}}}{\left(1-\mathrm{a}_{\mathrm{w}}\right)}\right]^{\frac{1}{2.8304^{* *}}}}
\end{aligned}
$$

where:

** - significant at 0.01 by t-test;

Xe - hygroscopic equilibrium moisture content, \% d.b.;

$\mathrm{T}$ - temperature, ${ }^{\circ} \mathrm{C}$; and,

$\mathrm{a}_{\mathrm{w}}$ - water activity, dimensionless.

The thermodynamic parameters differential enthalpy, differential entropy, enthalpy-entropy compensation theory and Gibbs free energy were calculated using the Eqs. 3-9 (Beristain et al., 1996; Madamba et al., 1996; Nkolo Meze'e et al., 2008).

$$
\begin{gathered}
\ln \left(\mathrm{a}_{\mathrm{w}}\right)=\frac{\Delta \mathrm{h}_{\mathrm{st}}}{\mathrm{RT}}-\frac{\Delta \mathrm{S}}{\mathrm{R}} \\
\Delta \mathrm{S}=\frac{\Delta \mathrm{h}_{\mathrm{st}}-\Delta \mathrm{G}}{\mathrm{T}_{\mathrm{a}}} \\
\Delta \mathrm{h}_{\mathrm{st}}=\mathrm{T}_{\mathrm{B}}(\Delta \mathrm{S})+\Delta \mathrm{G}_{\mathrm{B}} \\
\Delta \mathrm{G}=\mathrm{R} \mathrm{T}_{\mathrm{a}} \ln \left(\mathrm{a}_{\mathrm{w}}\right) \\
\mathrm{T}_{\mathrm{B}}=\hat{\mathrm{T}}_{\mathrm{B}} \pm \mathrm{t}_{\mathrm{m}-2, \alpha / 2 \sqrt{\operatorname{Var}\left(\mathrm{T}_{\mathrm{B}}\right)}} \\
\operatorname{Var}\left(\mathrm{T}_{\mathrm{B}}\right)=\frac{\sum\left(\frac{1}{\mathrm{~T}}\right)}{\left.(\mathrm{m}-2) \mathrm{h}_{\mathrm{st}}-\overline{\Delta \mathrm{G}_{\mathrm{B}}}-\hat{\mathrm{T}}_{\mathrm{B}} \Delta \mathrm{S}\right)^{2}} \\
(\Delta \mathrm{S}-\overline{\Delta \mathrm{S}})^{2}
\end{gathered}
$$

where:

$\Delta \mathrm{h}_{\mathrm{st}}$ - differential enthalpy of sorption, $\mathrm{kJ} \mathrm{kg}^{-1}$;

$\Delta \mathrm{S}^{\mathrm{st}}$ - differential entropy of sorption, $\mathrm{kJ} \mathrm{kg}^{-1} \mathrm{~K}^{-1}$;

$\mathrm{R}$ - universal gas constant $\left(8.314 \mathrm{~kJ} \mathrm{kmol}^{-1} \mathrm{~K}^{-1}\right)$, equal to $0.4619 \mathrm{~kJ} \mathrm{~kg}^{-1} \mathrm{~K}^{-1}$ for water vapor;

$\mathrm{T}_{\mathrm{a}} \quad$ - absolute temperature (K); 
$\Delta \mathrm{G}$ - Gibbs free energy, $\mathrm{kJ} \mathrm{kg}^{-1}$;

$\mathrm{T}_{\mathrm{B}} \quad$ - isokinetic temperature, $\mathrm{K}$;

$\Delta \mathrm{G}_{\mathrm{B}}-$ Gibbs free energy at isokinetic temperature, $\mathrm{kJ} \mathrm{kg}^{-1}$;

$\mathrm{T}$ - temperature $\left({ }^{\circ} \mathrm{C}\right)$;

$\mathrm{T}_{\mathrm{hm}}$ - harmonic mean temperature, $\mathrm{K}$;

$\mathrm{n}$ - number of temperatures used; and,

m - number enthalpy-entropy data pairs.

\section{Results AND Discussion}

The hygroscopic equilibrium moisture contents of 'Malagueta' pepper seeds obtained in the desorption process are greater than those obtained by adsorption in the entire range of water activity and temperatures studied (Figures 1A, B and $\mathrm{C})$, thus evidencing the phenomenon of hysteresis (Figure 1D).

The hysteresis of the pepper seeds decreased with the increase in temperature (Figure 1D), showing a similar behavior to those observed for 'Bode' pepper (Capsicum chinense L.) (Rodovalho et al., 2015), millet (Aviara et al., 2016) and castor beans (Goneli et al., 2016b). For temperatures of 30,40 and $50{ }^{\circ} \mathrm{C}$, the greatest magnitudes of hysteresis (3.54, 2.18 and $1.17 \%$ d.b.) were observed for $0.91,0.77$ and 0.44 (dimensionless) of water activity (Figure 1D).

The difference between the hygroscopic equilibrium moisture contents depends on the physical mechanism governing the movement of water from inside the product to its surface (Corrêa et al., 2014). Under high moisture content conditions, when almost all sorption sites are filled, desorption causes the shrinkage of the product and consequently reduces the available sorption sites (Mohsenin, 1986). Shrinkage reduces the diameter of the pores, leading to less water diffusion (Goneli et al., 2016b), and reduces the binding capacity of the water during a subsequent adsorption (Mohsenin, 1986).

The reduction in the moisture content of pepper seeds caused an exponential increase in the differential enthalpy of desorption and adsorption, with lower values for the adsorption process (Figure 2A). This trend is indicative of the hysteresis phenomenon, as observed for millet (Aviara et al., 2016) and castor bean (Goneli et al., 2016a).

The difference between differential enthalpies of desorption and adsorption decreased with the increase in moisture content, tending to remain constant. According to Madamba et al. (1996), when the moisture content is high, the water comes out more easily from the seeds, thus less enthalpy is used. On the other hand, when the moisture content is low, it is more difficult to remove water and, therefore, there is higher demand of enthalpy.

The values of the differential enthalpy of adsorption, for pepper seeds with moisture contents from 4.6 to $21.3 \%$ (d.b.), ranged from $1,153.029$ to $97.207 \mathrm{~kJ} \mathrm{~kg}^{-1}$, while the differential enthalpy of desorption within the moisture content range from 7.0 to $24.7 \%$ (d.b.) varied from $1,998.435$ to $149.079 \mathrm{~kJ} \mathrm{~kg}^{-1}$ (Figure 2A). In 'Cabacinha' pepper seeds with moisture content from 3.3 to $23.9 \%$ (d.b.), the differential enthalpy of desorption varied from 7.279 to $442.933 \mathrm{~kJ} \mathrm{~kg}^{-1}$ (Silva et al., 2016).

The differences between the differential enthalpy values observed for seeds of 'Malagueta' pepper (C. frutescens L.) and

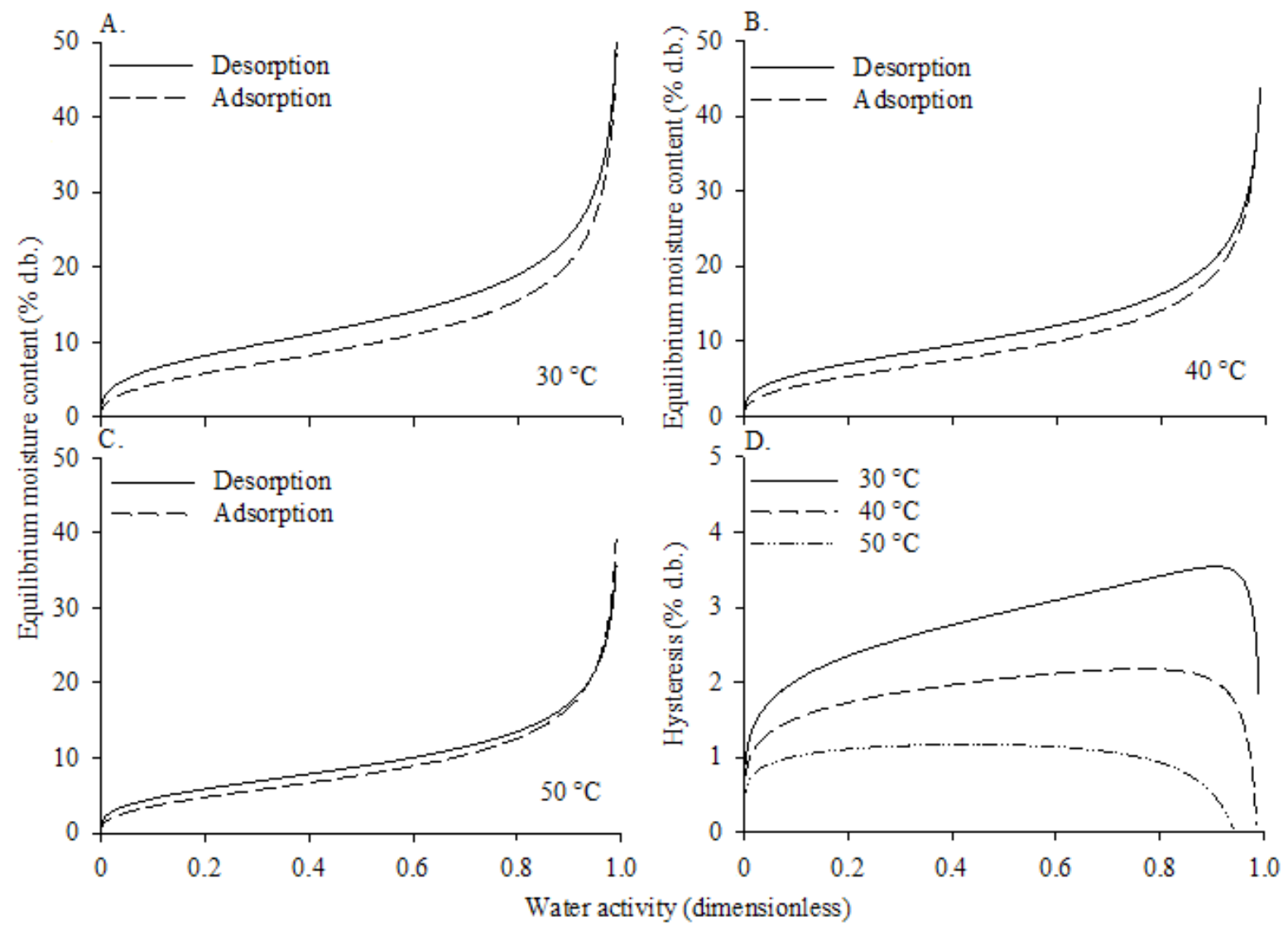

Figure 1. Estimated values of desorption and adsorption isotherms (A, B, C) and hysteresis (D) of 'Malagueta' pepper seeds (Capsicum frutescens L.) for different conditions of temperature and water activity 


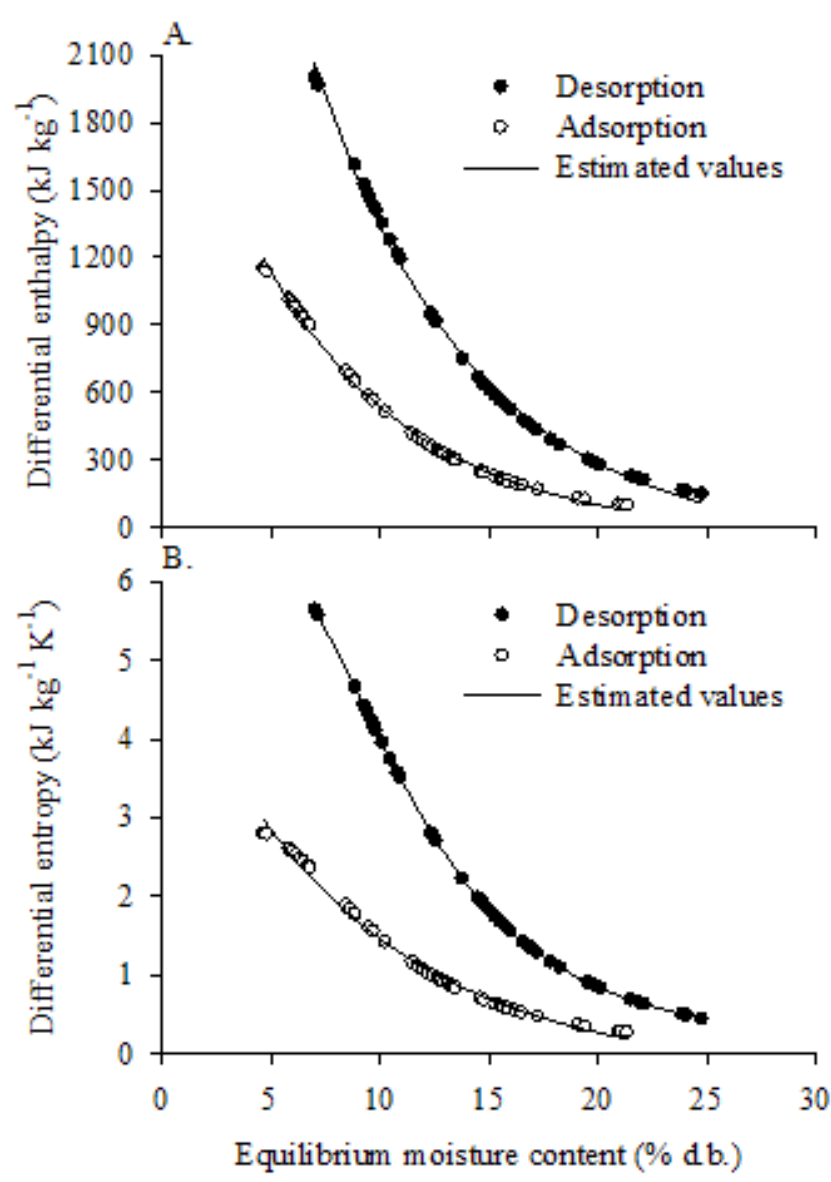

Figure 2. Experimental and estimated values of differential enthalpy (A) and differential entropy (B) of desorption and adsorption as a function of equilibrium moisture contents of 'Malagueta' pepper seeds (Capsicum frutescens L.)

'Cabacinha' pepper (C. chinense L.) can be attributed to the difference in chemical composition between the two species, as found for two cultivars of corn (Oliveira et al., 2010) and two varieties of millet (Aviara et al., 2016).

For the moisture content range from 4.6 to $21.3 \%$ (d.b.) and 7.0 to $24.7 \%$ (d.b.), the differential entropy of adsorption and desorption varied from 2.804 to $0.276 \mathrm{~kJ} \mathrm{~kg}^{-1} \mathrm{~K}^{-1}$ and from 5.643 to $0.447 \mathrm{~kJ} \mathrm{~kg}^{-1} \mathrm{~K}^{-1}$, respectively (Figure $2 \mathrm{~B}$ ). It is noted that the reduction in moisture content increases the differential entropy, as well as the difference between adsorption and desorption values.

Entropy has been related to the number of sorption sites available at a specific level of energy (Silva et al., 2015a). Therefore, the high values of entropy observed for the lowest moisture contents of pepper seeds demonstrate the reduction of movement and the degree of freedom of water molecules that are strongly bound to the active sites of the seeds. Under this condition, the energy needed to remove water bound to the active sites is greater compared with those that have high moisture content. This is because in the hydrated state, there is greater freedom for water molecules, which are weakly adsorbed to the seeds, to form the monolayer (Silva et al., 2015a; Yogendrarajah et al., 2015).

The high coefficients of determination $\left(\mathrm{R}^{2}>0.99\right)$ obtained by Eq. 5 and presented in Table 1 indicate the high degree of linearity of the enthalpy-entropy ratio for water desorption and
Table 1. Parameters obtained by the enthalpy-entropy ratio for the processes of desorption and adsorption in 'Malagueta' pepper seeds (Capsicum frutescens L.)

\begin{tabular}{cccc}
\hline Process & $\mathbf{T}_{\mathbf{B}}(\mathbf{K})$ & $\mathbf{\Delta G}_{\mathbf{B}}\left(\mathbf{k J ~ k g}^{-1}\right)$ & $\mathbf{R}^{2}$ \\
Desorption & 350.759 & -21.110 & 0.999 \\
Adsorption & 402.221 & -35.274 & 0.998 \\
\hline
\end{tabular}

adsorption in pepper seeds. This suggests the existence of the enthalpy-entropy compensation phenomenon for the processes of desorption and adsorption in 'Malagueta' pepper seeds.

Originally applied by Bell (1937), the enthalpy-entropy compensation theory is an important tool in evaluating water sorption mechanisms under different conditions, such as drying processes (Rizvi, 1995). It has been observed that generally the changes in enthalpy and entropy occur simultaneously (Oliveira et al., 2013; Corrêa et al., 2015; Goneli et al., 2016a, b; Silva et al., 2016), which according to Leffler (1995) allows to verify greater molecular interaction or bonds between molecules due to the reduction in the freedom or to the binding of the molecules in the system.

To test the validity of the enthalpy-entropy compensation phenomenon, Krug et al. (1976a,b) suggested that the isokinetic temperature $\left(\mathrm{T}_{\mathrm{B}}\right)$ should be different from the harmonic mean temperature $\left(\mathrm{T}_{\mathrm{hm}}\right)$. Thus, the magnitude of the isokinetic temperatures (Table 1$)$ for desorption $(350.76 \pm 3.57 \mathrm{~K}$ ) and adsorption (402.22 $\pm 10.04 \mathrm{~K})$ processes compared with the harmonic mean temperature $(311.45 \mathrm{~K})$, confirms that the isokinetic theory is valid for sorption processes in 'Malagueta' pepper seeds and corroborate the results obtained for seeds of cucumber (Corrêa et al., 2015), forage turnip (Sousa et al., 2015) and 'Cabacinha' pepper (Silva et al., 2016).

The isokinetic temperature has been used to characterize the temperature at which the product is in equilibrium, i.e., when all reactions occur simultaneously (Goneli et al., 2016a). For Leffler (1955), if $\mathrm{T}_{\mathrm{B}}>\mathrm{T}_{\mathrm{hm}}$, the sorption process is controlled by enthalpy; otherwise $\left(T_{B}<T_{h m}\right)$, the process is controlled by entropy. Therefore, the desorption and adsorption processes of 'Malagueta' pepper seeds are controlled by the enthalpy, following the same behavior of various agricultural products (Oliveira et al., 2013; Goneli et al., 2016a; Silva et al., 2016).

The increase in temperature led to reduction in Gibbs free energy of desorption (Figure 3A) and adsorption (Figure 3B), particularly for the desorption process. Gibbs free energy of desorption and adsorption, as well as the effect of temperature on this thermodynamic parameter, decreased at high moisture contents. It is known that Gibbs free energy is related to the work required to make the sorption sites available (Nkolo Meze'e et al., 2008). Therefore, the reduction of this variable with the increment in moisture content demonstrates the increase in the number of sites available for sorption.

The Gibbs free energy of desorption and adsorption showed positive values for the different temperatures and moisture contents analyzed (Figure 3). This trend is characteristic of an endothermic reaction (Goneli et al., 2016a), i.e., a reaction which requires the input of energy in the system for water desorption or adsorption to occur in the seeds (Oliveira et al., 2013; Sousa et al., 2015); in other words, water sorption processes in 'Malagueta' pepper seeds are not spontaneous. 


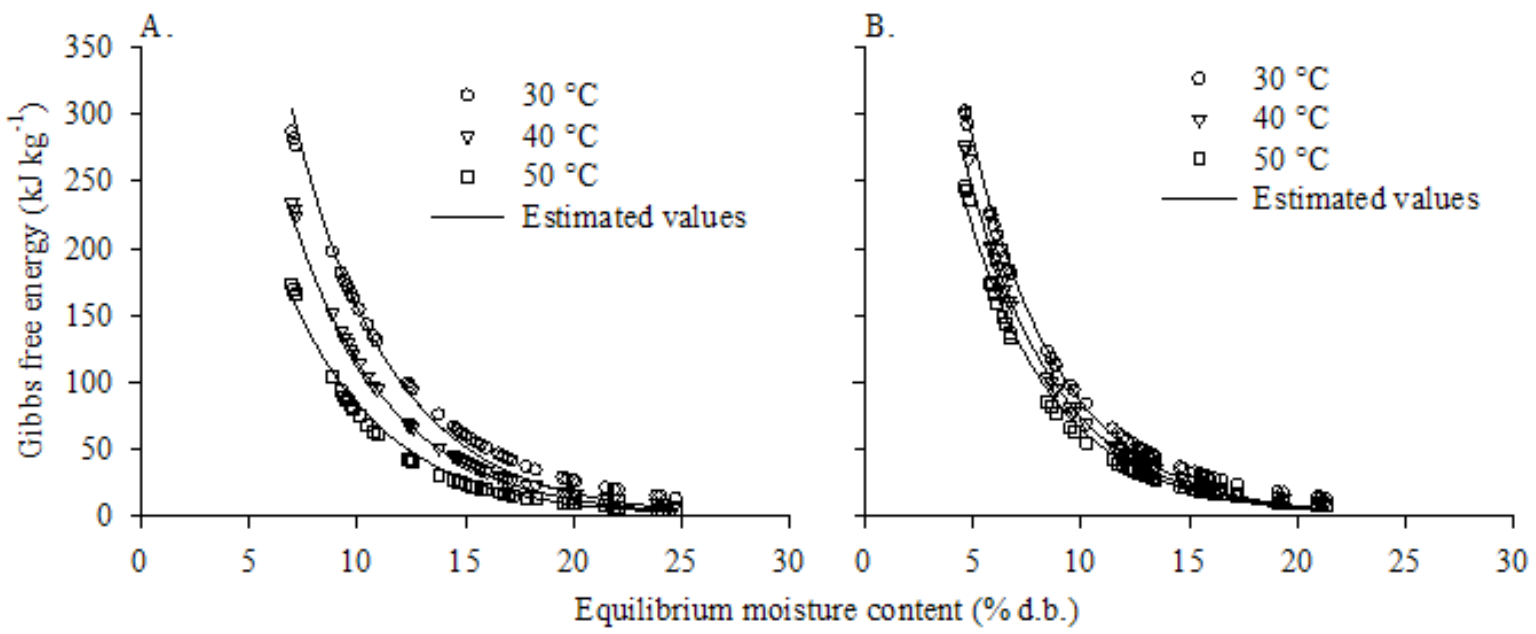

Figure 3. Experimental and estimated values of Gibbs free energy of desorption (A) and adsorption (B) as a function of temperature and equilibrium moisture content of 'Malagueta' pepper seeds (Capsicum frutescens L.)

The regression equations fitted to the values of differential enthalpy, differential entropy and Gibbs free energy of desorption and adsorption (Table 2) had a high degree of fit to experimental data $\left(\mathrm{R}^{2}>0.99\right)$ and can be used to estimate these thermodynamic parameters for the desorption and adsorption processes of 'Malagueta' pepper seeds with moisture contents from 7.0 to $24.7 \%$ (d.b.) and from 4.6 to $21.3 \%$ (d.b.), respectively, at temperatures of 30,40 and $50^{\circ} \mathrm{C}$.

Table 2. Regression equations and coefficients of determination for differential enthalpy $\left(\Delta \mathrm{h}_{\mathrm{st}}\right)$, differential entropy $(\Delta S)$ and Gibbs free energy $(\Delta \mathrm{G})$ of water adsorption and desorption in 'Malagueta' pepper seeds (Capsicum frutescens L.)

\begin{tabular}{|c|c|}
\hline Regression equations & $\overline{\mathbf{R}^{2}}$ \\
\hline \multicolumn{2}{|l|}{ Desorption } \\
\hline$\Delta \mathrm{h}_{\mathrm{st}}=-77.385^{\star \star}+5560.307^{\star \star} \exp \left(-0.137^{\star \star} \mathrm{Xe}\right)$ & 0.999 \\
\hline$\Delta S=-0.332^{\star \star}+15.064^{\star \star} \exp \left(-0.127^{\star \star} X e\right)$ & 0.998 \\
\hline$\Delta G=\left(-1277.526^{* \star} \ln (T)+5757.819^{* *}\right) \exp \left(-0.220^{* *} X e\right)$ & 0.996 \\
\hline \multicolumn{2}{|l|}{ Adsorption } \\
\hline$\Delta h_{s t}=-37.972^{* \star}+2398.093^{\star *} \exp \left(-0.143^{\star \star} X e\right)$ & 0.999 \\
\hline$\Delta S=-0.267^{\star \star}+5.599^{\star \star} \exp \left(-0.118^{\star \star} X e\right)$ & 0.997 \\
\hline$\Delta G=\left(-423.430^{* *} \ln (T)+2361.314^{* *}\right) \exp \left(-0.237^{\star *} X e\right)$ & 0.998 \\
\hline
\end{tabular}

\section{Conclusions}

1. The magnitude of hysteresis in 'Malagueta' pepper seeds decreases with the increment in temperature.

2. Differential enthalpy and differential entropy of adsorption and desorption increase with the reduction in the moisture content of pepper seeds, being higher for the desorption process.

3. For the studied ranges of moisture content, the differential enthalpies of adsorption and desorption varied from $1,153.029$ to $97.207 \mathrm{~kJ} \mathrm{~kg}^{-1}$ and from $1,998.435$ to 149.079 $\mathrm{kJ} \mathrm{kg}^{-1}$, respectively; whereas the differential entropy varied from 2.804 to $0.276 \mathrm{~kJ} \mathrm{~kg}^{-1} \mathrm{~K}^{-1}$ for adsorption and from 5.643 to $0.447 \mathrm{~kJ} \mathrm{~kg}^{-1} \mathrm{~K}^{-1}$ for desorption.

4. The enthalpy-entropy compensation theory is valid for water adsorption and desorption in pepper seeds, and these processes are controlled by enthalpy.

5. The water sorption process in pepper seeds is not spontaneous.

\section{ACKNOWLedgments}

To CNPq for granting the Scientific Initiation scholarship to the first author and to the IF Goiano for the essential support to the conduction of this study.

\section{Literature Cited}

Aviara, N. A.; Ojediran, J. O.; Marwan, S. I. U.; Raji, A. O. Effect of moisture sorption hysteresis on thermodynamic properties of two millet varieties. Agricultural Engineering International: CIGR Journal, v.18, p.363-383, 2016.

Bell, R. P. Relations between the energy and entropy of solution and their significance. Transactions of the Faraday Society, v.33, p.496501, 1937. https://doi.org/10.1039/tf9373300496

Beristain, C. I.; Garcia, H. S.; Azuara, E. Enthalpy-entropy compensation in food vapor adsorption. Journal of Food Engineering, v.30, p.405415, 1996. https://doi.org/10.1016/S0260-8774(96)00011-8

Brasil. Ministério da Agricultura e Reforma Agrária. Regras para análises de sementes. Brasília: MAPA/ACS, 2009. 399p.

Corrêa, P. C.; Botelho, F. M.; Botelho, S. de D. C. C.; Goneli, A. L. D. Isotermas de sorção de água de frutos de Coffea canefora. Revista Brasileira de Engenharia Agrícola e Ambiental, v.18, p.1047-1052, 2014. https://doi.org/10.1590/1807-1929/agriambi. v18n10p1047-1052

Corrêa, P. C.; Reis, M. F. T.; Oliveira, G. H. H. de; Oliveira, A. P. L. R. de; Botelho, F. M. Moisture desorption isotherms of cucumber seeds: Modeling and thermodynamic properties. Journal of Seed Science, v.37, p.218-225, 2015. https://doi.org/10.1590/2317$1545 \mathrm{v} 37 \mathrm{n} 3149549$

Costa, L. M.; Resende, O.; Oliveira, D. E. C. de. Isotermas de dessorção e calor isostérico dos frutos de crambe. Revista Brasileira de Engenharia Agrícola e Ambiental, v.17, p.412-418, 2013. https:// doi.org/10.1590/S1415-43662013000400009

Costa, L. M.; Resende, O.; Oliveira, D. E. C. de. Determinação das isotermas de equilíbrio higroscópico de frutos de crambe pelo método dinâmico. Bioscience Journal, v.31, p.382-391, 2015. https://doi.org/10.14393/BJ-v31n2a2015-22337

FAOSTAT - Food and Agriculture Organization of the United Nations. Available on: <http://www.fao.org/faostat/en/>. Access on: 2018. 
Goneli, A. L. D.; Corrêa, P. C.; Oliveira, G. H. H. de; Oliveira, A. P. L. R. de; Orlando, R. C. Moisture sorption isotherms of castor beans. Part 2: Termodynamic properties. Revista Brasileira de Engenharia Agrícola e Ambiental, v.20, p.757-762, 2016a. https:// doi.org/10.1590/1807-1929/agriambi.v20n8p757-762

Goneli, A. L. D.; Corrêa, P. C.; Oliveira, G. H. H. de; Resende, O.; Mauad, M. Moisture sorption isotherms of castor beans. Part 1: Mathematical modeling and hysteresis. Revista Brasileira de Engenharia Agrícola e Ambiental, v.20, p.751-756, 2016b. https:// doi.org/10.1590/1807-1929/agriambi.v20n8p751-756

Heinrich, A. G.; Ferraz, R. M.; Ragassi, C. F.; Reifschneider, F. J. B. Caracterização e avaliação de progênies autofecundadas de pimenta biquinho salmão. Horticultura Brasileira, v.33, p.465470, 2015. https://doi.org/10.1590/S0102-053620150000400010

Krug, R. R.; Hunter, W. G.; Grieger, R. A. Enthalpy-entropy compensation: 1 - Some fundamental statistical problems associated with the analysis of van't Hoff and Arrhenius data. Journal of Physical Chemistry, v.80, p.2335-2341, 1976a. https:// doi.org/10.1021/j100562a006

Krug, R. R.; Hunter, W. G.; Grieger, R. A. Enthalpy-entropy compensation: 2 - Separation of the chemical from the statistical effect. Journal of Physical Chemistry, v.80, p.2341-2351, 1976b. https://doi.org/10.1021/j100562a007

Leffler, J. E. The enthalpy-entropy relationship and its implications for organic chemistry. The Journal of Organic Chemistry, v.20, p.1202-1231, 1955. https://doi.org/10.1021/jo01126a009

Madamba, P. S.; Driscoll, R. H.; Buchkle, K. A. Enthalpy-entropy compensation models for sorption and browning of garlic. Journal of Food Engineering, v.28, p.109-119, 1996. https://doi. org/10.1016/0260-8774(94)00072-7

Mohsenin, N. N. Physical properties of plant and animal materials. 2.ed. New York: Gordon and Breach Publishers, 1986. 891p.

Nkolo Meze'e, Y. N.; Ngamveng, J. N.; Bardet, S. Effect of enthalpyentropy compensation during sorption of water vapour in tropical woods: The case of Bubinga (Guibourtia tessmanii J. L'eonard; G. Pellegriniana J. L.). Thermochimica Acta, v.468, p.1-5, 2008. https://doi.org/10.1016/j.tca.2007.11.002

Oliveira, D. E. C. de; Resende, O.; Smaniotto, T. A. de S.; Sousa, K. A. de; Campos, R. C. Propriedades termodinâmicas de grãos de milho para diferentes teores de água de equilíbrio. Pesquisa Agropecuária Tropical, v.43, p.50-56, 2013. https://doi. org/10.1590/S1983-40632013000100007
Oliveira, G. H. H. de; Corrêa, P. C.; Araújo, E. F.; Magalhães, D. S. Desorption isotherms and thermodynamic properties of sweet corn cultivars (Zea mays L.). International Journal of Food Science and Technology, v.45, p.546-554, 2010. https://doi.org/10.1111/ j.1365-2621.2009.02163.x

Rizvi, S. S. H. Thermodynamic properties of foods in dehydration. In: Rao, M. A.; Rizvi, S. S. H. Engineering properties of foods. New York: Academic Press, 1995. Chap.4, p.223-309.

Rodovalho, R. S.; Silva, I. L.; Silva, H. W. da; Rossetto, C. A. V. Isotermas de sorção dos grãos de pimenta bode. Revista Agrotecnologia, v.6, p.80-101, 2015. https://doi.org/10.12971/2179-5959/ agrotecnologia.v6n1p80-101

Silva, C. L. O. C. e; Faria, L. J. G. de; Costa, C. M. L. Comportamento higroscópico de partes aéreas de pimenta-de-macaco (Piper aduncum L.). Revista Brasileira de Engenharia Agrícola e Ambiental, v.19, p.376-381, 2015a. https://doi.org/10.1590/18071929/agriambi.v19n4p376-381

Silva, H. W. da; Costa, L. M.; Resende, O.; Oliveira, D. E. C. de; Soares, R. S.; Vale, L. S. R. Higroscopicidade das sementes de pimenta (Capsicum chinense L.) Revista Brasileira de Engenharia Agrícola e Ambiental, v.19, p.780-784, 2015b. https://doi.org/10.1590/18071929/agriambi.v19n8p780-784

Silva, H. W. da; Costa, L. M.; Resende, O.; Oliveira, D. E. C. de; Soares, R. S.; Vale, L. S. R. Thermodynamic properties of pepper seeds - Variety 'Cabacinha'. Científica, v.44, p.14-22, 2016. https://doi. org/10.15361/1984-5529.2016v44n1p14-22

Silva, H. W. da; Rodovalho, R. S. Isotermas de dessorção das sementes de pimenta malagueta. Global Science and Technology, v.5, p.3239, 2012. https://doi.org/10.14688/1984-3801/gst.v5n1p32-39

Silva, H. W. da; Rodovalho, R. S. Adsorption isotherms and vaporization latent heat of malagueta pepper seeds. Científica, v.44, p.5-13, 2016. https://doi.org/10.15361/1984-5529.2016v44n1p5-13

Sousa, K. A. de; Resende, O.; Goneli, A. L. D.; Smaniotto, T. A. de S.; Oliveira, D. E. C. de. Thermodynamic properties of water desorption of forage turnip seeds. Acta Scientiarum. Agronomy, v.37, p.11-19, 2015. https://doi.org/10.4025/actasciagron. v37i1.19333

Yogendrarajah, P.; Samapundo, S.; Devlieghere, F.; Saeger, S. de; Meulenaer, B. de. Moisture sorption isotherms and thermodynamic properties of whole black peppercorns (Piper nigrum L.). LWT - Food Science and Technology, v.64, p.177-188, 2015. https://doi.org/10.1016/j.lwt.2015.05.045 